\title{
Obituário: Reinaldo Calixto de Campos
}

por Florence Moellmann Cordeiro de Farias

Data de publicação na Web: 20 de Fevereiro de 2012 Recebido em 18 de Fevereiro de 2012 Aceito para publicação em 20 de Fevereiro de 2012

Quando me perguntaram se eu podia escrever o obituário de Reinaldo, aceitei achando que aliviaria esse bolo que sinto na garganta desde aquela manhã em que soube que Reinaldo havia

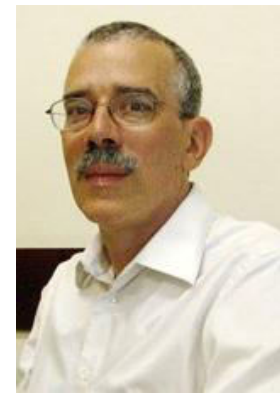

falecido na véspera, dia 7 de fevereiro de 2012. Não imaginei, entretanto que seria tão difícil. Falar de quem? Do pesquisador na área de Química Analítica Prof. Dr. Reinaldo Calixto de Campos, bolsista de produtividade $1 \mathrm{C}$ do CNPq, com 112 trabalhos publicados, 2 capítulos de livro, orientador de 17 dissertações de mestrado e 18 teses de doutorado? Do Professor? Reinaldo sempre dizia que o que ele mais gostava era ser professor e, por isso, dar aula era o que ele sabia fazer melhor. Aliás, Reinaldo aniversariava em 15 de outubro, Dia do Professor. O grande número de ex-alunos, desde o seu tempo na Escola Técnica Federal de Química (atual IFF) até os dias de hoje (PUC), presentes a cerimônia fúnebre, sempre com o mesmo comentário: "Era um excelente professor" dá bem a dimensão do que era o Prof. Calixto.

Falar do Decano do CTC da PUC Rio? Não poderia, pois deste aspecto administrativo nunca participei. No entanto, a admiração manifestada desde o Reitor até o funcionário mais simples, evidencia o que todos nós mais próximos conhecíamos bem: sua capacidade de agregar, a certeza que ele sempre teve de que o exercício da liderança passava longe do autoritarismo. Reinaldo tinha a capacidade ímpar de perceber o que cada um tinha de melhor, descartar os defeitos e cultivar as qualidades.

Mais do que tudo, Reinaldo possuía uma preocupação enorme com o Ensino Médio desse país. Raramente encontramos na academia um professor pesquisador com a clareza que ele tinha dos problemas tanto ao nível do macro (estruturais) quanto do micro, do dia a dia escolar. E atuava. Além de suas pesquisas em química analítica, principalmente na área da espectroscopia de Absorção Atômica, Reinaldo atuava em vários projetos de ensino, tanto como colaborador, quanto como coordenador. Através desses projetos Reinaldo conseguiu levar para dentro da PUC o professor do Ensino Médio e traçar uma via de mão dupla Ensino Superior / Ensino Médio. Reinaldo, com certeza, vai deixar uma lacuna na Educação Brasileira.

Falar do amigo? Não há palavras. Sempre, muito antes de sua morte, que escuto a música: "Amigo é casa - Cem anos de choro", de Hermínio Bello de Carvalho e Capiba: principalmente no trecho em que dizem [...] Amigo é pra ficar, se chegar, se achegar, se abraçar, se beijar, se louvar, bendizer. Amigo a gente acolhe, recolhe e agasalha e oferece lugar pra dormir e comer. Amigo que é amigo não puxa tapete e oferece pra gente o melhor que tem e o que nem tem quando não tem, finge que tem, faz o que pode e o seu coração reparte que nem pão [...]", me vem a figura de Reinaldo.

Hoje faz uma semana que Reinaldo se foi. Conforme o convite feito pela PUC-Rio não fomos a sua missa de sétimo dia, mas sim a celebração de sua vida. Nela, foi lido um e-mail que recebemos de Reinaldo no dia 31 de dezembro e que vou reproduzilo aqui. Ele reflete bem quem era Reinaldo.

\section{Queridos amigos,}

Como vocês sabem, tive mesmo que operar. Tentei resolver o problema, ao longo de 2011, com um protocolo médico recentemente sugerido, que poderia evitar a operação: houve resposta, mas não o suficiente para evitar o bisturi. Voltei finalmente para casa, depois de 15 longos dias. Era para ficar 4. É que houve um tal de ilioparalítico, que é uma espécie de paralisia do intestino... Eu tava meio depletado, e isso não aparecia nos inúmeros exames que fiz, teve a questão da anestesia e a operação em si, que durou 6 horas....lsso tudo 
contribuiu para o tal ilio. A equipe médica foi 10, não tive um minuto desassistido, pelo menos 2 visitas por dia, de um ou outro alguém da equipe. Eles têm um clínico, tb, que me via todos os dias. Mas, é interessante que a gente aprende que nosso drama não é único, as pessoas nos contam suas histórias, que passam por dificuldades bem maiores. Falo isso não para dizer que foi bom, nunca é, mas que esteve longe de ser o pior. Na internação a gente passa por fases, muitas fases, ansiedade, tristeza, excitação, angústia. Não entrei esperando ficar o tempo que fiquei. Tive sorte de ter acesso ao que melhor há de cuidado médico no Rio, não só quanto à Infra, e o quarto, que era ótimo, mas quanto ao cuidado em si mesmo, com enfermeiras $e$ auxiliares de enfermagem maravilhosas, todas. Muitas histórias humanas, de grande generosidade, desta grande alma deste grande povo brasileiro. Chega a dar uma certa vergonha na gente, de tão voltados muitas vezes que somos para nossos planos pessoais de vida, ver como a solidariedade brota espontânea nas pessoas mais simples. Que estão felizes sim por que estão podendo ter um pouco mais de acesso (a famosa nova classe (C), é claro, mas não fazem disso o cerne de suas vidas. De nada adiantaria tanta tecnologia sem este carinho, que juro, era sincero, pois não há treinamento que ensine carinho. Deixei para elas, um "Diploma de Honra ao Mérito", afinal, elas me chamavam de "Professor", o que me deu direitos de conferir diplomas, colocando nele que eu havia ali aprendido uma outra dimensão da palavra cuidar.

Estou em casa há 3 dias, é uma delícia, comidinha caseira, não há igual, mas ainda estou meio fraquinho, ainda retomando a nutrição oral completa, pois parece que remexe tudo, ainda tenho um tanto de gases, cólicas, ainda tem que ter suplementação (um tipo sustagem, mais sofisticado), não posso ficar parado depois das refeições, nem posso falar muito (cansa), nem tenho altos poderes de concentração, e a cicatrização dói, as vezes. Aí a gente vê como $T V$, novela em especial, é bom: não consome quase nada da nossa energia. Não sei quanto tempo vou ficar nesta recuperação, sei que vai ter que ser feita com calma, vou ter que ter paciência. Já estou comendo mais ou menos $50 \%$ do que comia. Todos os prognósticos são positivos no sentido da cura solução total do problema, mas há que se ter paciência na recuperação.

Não posso terminar sem agradecer a torcida de vocês, que sei que foi grande, o carinho, os inúmeros mails, os telefonemas, os santinhos, a água benta, etc, $e$ dividir com vocês o como minha família foi importante, como é envolvente ver seus filhos, a quem você sempre proveu, estarem lá a te cuidar. Mãe, irmã, sobrinho, até esta turma às vezes estranha na vida, que são os cunhados $e$ a sogra. Sem falar no sorriso e na alegria do João, que foi lá algumas vezes me levar vida. Mas, não posso deixar de destacar o apoio da Teresa, sempre carinhosa, otimista, compreensiva, nunca impaciente. Como as mulheres são generosas! Eu tirei a sorte grande, mas devo confessar que não foi só sorte, foi uma daquelas descobertas que você faz porque faz parte de você fazê-la.

Bem, e 2012? Que seja antes de tudo de PAZ e SAÚDE, pra vocês. De posse destes dois, sei do que vocês são capazes de realizar, e as coisas virão naturalmente, como sempre vieram.

Beijos no coração

Reinaldo.

Universidade Federal Fluminense, Departamento de Química Orgânica, Instituto de Química, Campus do Valonguinho, Centro, Niterói, Rio de Janeiro, Brasil, 24020-150.

Mgqoflor@vm.uff.br 